\title{
THE AGRONOMIC PERFORMANCE AND ACCEPTABILITY OF ORANGE FLESHED SWEETPOTATO VARIETIES IN THE LAKE ZONE OF TANZANIA
}

\author{
H.P. KULEMBEKA, C.K. RUGUTU, E. KANJU', B. CHIRIMI, E. RWIZA and R. AMOUR \\ Agricultural Research Institute, Ukiriguru, P. O Box 1433, Mwanza, Tanzania \\ 'IITA, P.O. Box 6226 Dar es salaam, Tanzania
}

\begin{abstract}
The introduction of improved orange-fleshed sweetpotato (Ipomea batatas) varieties from the International Potato Centre (CIP) was a result of recognising the negative health effects of vitamin A deficiency in Tanzania. Orange varieties, which are rich in $\beta$-carotene, were considered one of the sustainable strategies for addressing Vitamin A deficiency. Seven varieties from CIP, five of which were orange-fleshed, were tested on farm for two seasons (2001-2002) in the Lake zone of Tanzania. Different sweetpotato recipes were prepared and tasted as alternative to boiled sweetpotato roots. Among the introduced orange varieties, Zapallo, NC 1560 and Tainung No 64 produced between 6.04 and $\mathrm{J}] .86 \mathrm{tha}^{-1}$ of fresh total root yield compared to $7.59 \mathrm{t} \mathrm{ha} \mathrm{h}^{-1}$ of the control variety. Mafutha and Japon tresimesino gave poor yields. Farmers ranked high Zapallo, Tainung No. 64 and NC 1560 for agronomic performance. However, Mafutha, Japon tresimesino and Tainung No. 64 were rated high for cooking quality. Zapallo and NC 1560 were rated high for dry texture. For children, internal root colour was the most important attribute for accepting a variety. Sweetpotato products prepared from orange fleshed varieties were preferred more by both adults and children than those prepared from white fleshed varieties. The over all acceptability of orange varieties and sweetpotato products was high.
\end{abstract}

Key Words: $\beta$-carotine, CIP, Ipomea batatas

\section{RÉSUMÉ}

L'introduction des variétés améliorées de la patate (Ipomea batatas) douce orange graissée par le Centre International de la Patate (CIP) était le résultat de la reconnaissance d 'effets négatifs de la carence en vitamine $A$ en Tanzanie. Les variétés oranges qui sont riches en carotène- $\beta$, étaient considéré comme l'une des stratégies durables pour résoudre la carence en vitamine A. Sept variétés du CIP dont cinq oranges graissés, étaient testées sur fermes pour deux saisons (2001-2002) dans la région du lac Tanganyika. Différentes recettes de la patate douce étaient préparées et goûtée comme alternatives a la patate douce. Parmi les variétés oranges introduites, Zapallas, NC 1560 et Tainung No 64 ont produit entre 6.04 et $11.86 \mathrm{tha}^{-1}$ des racines fraîches comparé a $7.59 \mathrm{tha}$ de la variété de contrôle. Mafutha et Japon tresimesino donnerent des rendements faibles. Les fermiers classèrent supérieure les performances agronomiques de Zapallo, Tainung No 64 et NC1560. Cependant, Mafutha, Japon tresimesino et Tainung No 64 étaient bien cotés pour la cuisson. Zapallo et NC1560 étaient bien cotés pour la texture à sec. Pour les enfants, la couleur interne était l'attribut le plus important pour accepter la variété. Les produits de la patate douce préparés des variétés orange graissées étaient préférés par les enfants et les adultes que les ceux préparés des variétés graissées de couleur blanche. L'acceptabilité des variétés oranges et les produits associés étaịent élevés.

Mots Clés: Carotène- $\beta$, CIP, Ipomea batatas 


\section{INTRODUCTION}

The importance of sweetpotato (Ipomoea batatas) as a food security crop and source of essential nutrients cannot be overemphasized. In Tanzania, sweetpotato is one of the most important staple food crops that is consumed throughout the country by most people of all categories. It is the second most important root and tuber crop in most parts of the country, after cassava (Manihot esculenta Crantz) (Kapinga et al., 1995). Together with cassava, it plays a significant role not only as a food security crop, but also as a potential commercial and nutrition crop. Sweetpotato is particularly important in the lake, eastern, western, southern highlands and northern zones. Current trends indicate an increase in acreage under sweetpotato production due to commercialisation of the crop. However, there are limiting factors to increased sweetpotato production. Studies conducted in Magu district in the Lake zone indicated that low sweetpotato production was caused by sweetpotato virus diseases, weevils, continuous use of varieties despite root yield degeneration, critical shortage of planting materials of superior varieties, and poor soils (Wamara, 1997). These constraints and the increasing understanding among farming communities that white-fleshed varieties have low contents of beta-carotene, a precursor to vitamin $\mathrm{A}$, is increasing the demand for improved sweetpoiato varieties.

The use of foods rich in vitamin A to combat vitamin A deficiencies is gaining importance in most parts of Africa. Increasing the consumption of foods rich in vitamin $\mathrm{A}$ is considered one of the food-based strategies in addressing vitamin A deficiency in the communities. One of the cheap sources of vitamin $A$ is orange-fleshed sweetpotato varieties because they are rich in pro-Vitamin A. Increasing consumption of orange-fleshed sweetpotato at household level can increase supplementation of the diet with vitamin A. Where vitamin A rich food items are not readily available, use of sweetpotato orange varieties can provide the answer. Vitamin A and other micronutrients like iron and iodine are substance that cannot be synthesized in the human body and they, or their precursor chemicals, must be provided through the diet (VITAA 2001). Vitamin A is essential for the maintenance of the immune system of the body and therefore many diseases can be prevented or reduced when adequate amounts of vitamin $\mathrm{A}$ are included in the diets. When compared to other food staples sweetpotato (orange varieties) has more potential vitamin A value. For example $100 \mathrm{~g}$ of golden rice (transformed rice) has 10-20 $\mu \mathrm{g}$ retinol equivalent (RE), which provides 2.5 $5.1 \%$ of recommended daily requirement (RDA) while orange-fleshed sweetpotato has 625-1250 $\mu \mathrm{g}$ RE which provides more than $100 \%$ of recommended daily requirement of Vitamin $A$ (Walker et al., 2001). The pro-Vitamin A content of the sweetpotato varieties is higher than most crops and increases with the increase in the intensity of orange flesh colour of the root (Low et al., 1996). This shows how important orangefleshed sweetpotato is as a source of the muchneeded micronutrient. The fact that sweetpotato is cheaply available compared to other food based sources of vitamin A and the wide acceptability of the orange varieties can lead to sustainable solution to vitamin A deficiency in a cost effective way. The nutritional aspects of the crop show that apart from vitamin A sweetpotato is a good source of energy. Early maturing sweetpotato varieties yield higher amounts of edible energy per unit area per unit time than all other major staples (Woolfe, 1992).

Efforts to promote the use of sweetpotato to combat vitamin A deficiencies were started by the National Root and Tuber Crops Research Program, by introduction and evaluation of orange-fleshed sweetpotato varieties. The introduction of improved orange-fleshed sweetpotato varieties from CIP was the result of recognising the negative health effects of vitamin A deficiency. Orange varieties, which are rich in beta-carotene, were considered one of the sustainable strategies in addressing problems associated with Vitamin A deficiency. Vitamin A deficiencies is a problem in most farming communities of the lake zone of Tanzania, particularly in Shinyanga district (Ngendello, 2000, pers. Comm.). To address this problem it was found necessary to test on-farm and promote the utilisation of the orange-fleshed sweetpotato varieties. A number of white-fleshed sweetpotato clones had been introduced and tested on farm and most of them had been widely accepted but none of the orange-fleshed sweetpotato 
varieties had ever been introduced at farm level in the lake zone.

\section{MATERIALS AND METHODS}

The study was conducted on-farm in the lake zone in Tanzania, for two seasons (2001-2002) especially, the sites were in Magu, Kwimba and Shinyanga districts. Farmer groups were used to conduct the trials in collaboration with nonGovernmental Organisations (NGOs) (CARE International in Magu and WINROCK International in Shinyanga).

In Magu districl, CARE-Magu facilitated in farmers selection and land preparation through their organized farmer groups called Input Marketing Association (IMA) consisting mainly of women. Ten farmers were selected, two from each of the IMA groups at Nyakahoja, Salongwe, $\mathrm{Ng}$ 'haya, Lunala and Nyanguge. Out of the ten farmers nine were women and all belonged to the low-income category. All the areas where the varieties were evaluated in this district are characterised by low annual rainfall and sandy loam soils. In these areas, sweetpotato is a major food staple

Winrock International, on the other hand, organised farmer selection, land preparation and planting in Shinyanga district. Farmers were selected from two organised farmer groups at Ikonda and Nobhla villages. Twelve farmers evaluated the varieties in this district. Here again, the farmers involved in the trial were mostly women who belonged to the low-income category. Shinyanga rural district is characterised by a semi-arid climate and the sites were dominated by clay loam soils. Five women farmers from the Farmers Research Group (FRG) at Kishili,
Kwimba district were selected for evaluation of the clones.

The materials for on-farm testing consisted of white and orange-fleshed sweetpotato clones. They included Jitihada, Sinia B and Simama, which are officially released varieties in Tanzania. Other varieties were Cemsa 74-228, Zapallo, Japon tresimesino, Tainung No.64, NC 1560 and Mafutha; all introductions from CIP Nairobi. The characteristics of the clones tested are presented in Table 1. A local check was included in each of the villages, namely, Mwanamulwa in Magu and Local Sinia in Shinyanga.

A randomised complete block design was used with each farmer as a replicate. Planting was done on ridges, (the common practice), at a spacing of $30 \mathrm{~cm}$ between plants. Each plot contained four ridges (rows) each $6.0 \mathrm{~m}$ long. Management of the trials was entirely by the farmer assisted by the group members.

Harvesting was done $4-5$ months after planting. Data were recorded on storage root yield and other root characteristics, weevil damage leaf yield and harvest index. A group of non- and participating farmers were involved in agronomic assessment of clones in the field and cooking qualities based on attributes set by farmers. Important attributes used in the assessment were: resistance to pests and diseases, foliage cover, early maturity, suitability of leaves as vegetable, drought tolerance, and root characteristics such as root size, shape, skin, flesh colour and number of roots per plant. The criteria used for cooking quality were taste, appearance, dry matter content and fibrousness. Acceptability of the varieties was assessed using a scale of $\mid-5$, where 1 meant very poor and 5 very good. Farmer groups did pair wise comparisons of the clones to obtain rankings.

TABLE 1. Characteristics of the clones evaluated at Ikonda and Magu in Tanzania

\begin{tabular}{llll}
\hline Clone/ variety & Code name & Skin colour & Flesh colour \\
\hline Jitihada & SP93/2 & Cream & Cream \\
Sinia & Sinia B & Purple & Yellow \\
Simama & SPN/O & Cream & Cream/Yellow \\
Cemsa74-228 & CIP400004 & Cream & White \\
Zapallo & CIP 420027 & Brownish orange & Orange \\
Japon tresimesino selecto & CIP 420009 & Brownish orange & Orange \\
Tainung No.64 & CIP 440189 & Purplish cream & Orange \\
NC1560 & CIP 440093 & Brownish purple & Orange \\
Mafutha & - & Purplish cream & Orange \\
\hline
\end{tabular}


Farmers and school children did taste testing of sweetpotato products variously prepared. The products included: cakes, pancake (chapati), doughnuts, buns (maandazi) and kaimati. Internal and external colour, and overall acceptability were assessed by scoring using the scale of $1-5$ as described above.

All the data collected were subjected to statistical analysis using Analysis of Variance, Genstat 5.32 for Windows. Means were separated by using Least Significance Differences at 5\% probability.

\section{RESULTS AND DISCUSSION}

Agronomic performance. The agronomic performance of the clones is indicated in Table 2. Clones tested at Ikonda had $>83 \%$ of plants surviving until harvesting. The average plant survival was $92 \%$. In Magu district plant survival percent ranged from $\mathrm{t} 80.0 \%$ at Cemsa $74-228$ to $95.0 \%$ recorded from Jitihada. The average plant population at harvest was $89 \%$ which can be rated as good. At all sites, significant differences $(\mathrm{P} \leq 0.05)$ were observed between clones with respect to plant population recorded at harvest. This might imply varying potentials of the varietics to adapt to the new environment and weather conditions.

The average fresh storage root yield obtained at Ikonda was about $8 \mathrm{tha}^{-1}$. Zapallo gave the highest yield of fresh storage roots of $10.9 \mathrm{tha}^{-1}$. Nevertheless, this was not significantly different from the root yield obtained from Tainung No 64 (9.4 $\mathrm{tha}^{-1}$ ), Jitihada (9.2 $\mathrm{tha}^{-1}$ ) and Cems74-228 (9.6 $\mathrm{tha}^{-1}$ ). Japon tresimesino the lowest yielding clone at Ikonda (4.1 $\left.\mathrm{t} \mathrm{ha}^{-1}\right)$ had a large number of small roots, implying that it might be late maturing.

On the other hand, in Magu, roots of Zapallo had started to rot by the time of harvest, indicating a possibility of early maturity. The local check recorded about $6 \mathrm{tha}^{-1}$ of storage root yield. Most of the clones except Sinia, recorded higher root than foliage yield which led to higher harvest indices (Table 3 ).

Storage root yield obtained from Magu was lower than that from Ikonda in Shinyanga, but the yield trend was generally the same (Table 3). Like in Shiny anga, Zapallo had the highest storage root yield, with the mean of $8.0 \mathrm{tha}^{-1}$, and Japon tresimesino again having the lowest yield ( $3.5 \mathrm{t}$ $\left.\mathrm{ha}^{-1}\right)$. In most fields, Japon tresimesino as at Ikonda, produced more smaller roots than other clones. The higher mean root yield obtained in Shinyanga than in Magu was partly due to higher rainfall obfained at the former during planting. In some villages of Magu, planting was followed by dry spells. The other reason could have been differences in soil types. Farmers' fields in Shinyanga are dominated by sandy to clay loams unlike Magu where the fields are mostly sand soil. Despite the relatively lower root yield in Magu, clones like Zapallo, Cemsa 74-228, Jitihada and NC 1560 performed relatively better than other varieties. These superior varieties produced root

TABLE 2. Plant population and number of roots per plant of sweetpotato varieties evaluated on-tarm at Ikonda, Shinyanga district and five villages in Magu district in 2001

\begin{tabular}{|c|c|c|c|c|c|c|c|c|}
\hline \multirow[t]{2}{*}{ Variety } & \multicolumn{2}{|c|}{$\begin{array}{l}\text { Plant population } \\
\text { at harvest } \%\end{array}$} & \multicolumn{2}{|c|}{$\begin{array}{l}\text { Number of large } \\
\text { roots/ plant }\end{array}$} & \multicolumn{2}{|c|}{$\begin{array}{l}\text { Number of small } \\
\text { roots/ plant }\end{array}$} & \multicolumn{2}{|c|}{$\begin{array}{l}\text { Total number of } \\
\text { roots/ plant }\end{array}$} \\
\hline & lkonda & Magu & Ikonda & Magu & Ikonda & Magu & Ikonda & Magu \\
\hline Cemsa74-228 & 88.61 & 80.19 & 2.05 & 1.60 & 0.45 & 0.40 & 2.50 & 2.01 \\
\hline Japon tresimento & 95.00 & 91.48 & 1.32 & 1.00 & 1.86 & 1.16 & 3.18 & 2.16 \\
\hline Jitihada & 90.00 & 95.37 & 1.74 & 1.35 & 0.46 & 0.35 & 2.20 & 1.70 \\
\hline Sinia & 95.56 & 87.04 & 1.31 & 1.14 & 1.04 & 0.55 & 2.34 & 1.69 \\
\hline Zapalio & 95.00 & 91.67 & 2.41 & 2.15 & 0.49 & 0.64 & 2.91 & 2.79 \\
\hline Tainung No.64 & 83.06 & - & 2.68 & - & 1.69 & - & 4.37 & - \\
\hline NC 1560 & - & 85.00 & - & 2.52 & - & 1.62 & - & 4.14 \\
\hline Local check & 93.89 & 92.22 & 2.32 & 1.60 & 2.10 & 1.07 & 4.42 & 2.67 \\
\hline Mean & 91.59 & 88.95 & 1.98 & 1.63 & 1.16 & 0.83 & 3.13 & 2.45 \\
\hline CV \% & 6.7 & 7.9 & 21.7 & 28.4 & 28.8 & 51.50 & 15.50 & 30.3 \\
\hline $\operatorname{LSD}(0.05)$ & $7.3^{*}$ & $6.65^{\star}$ & $0.51^{* *}$ & $0.44^{* *}$ & $0.39^{* *}$ & $0.40^{\star \star}$ & $0.58^{\star \star}$ & $0.70^{\star *}$ \\
\hline
\end{tabular}


yields, which were not significantly variable among them but significantly $(\mathrm{P}=0.05)$ higher than the other varietics. The four varieties also recorded harvest indices greater than 0.50 (Table 3). These results suggest relatively good efficiency in allocating photosynthetic products to the roots.

At Kishili, the agronomic performance of the clones in the second season (2002), was far better than in 2001. Root yield obtained in 2001 was very poor (data not presented) with most clones recording zero yiclds because of low precipitation.
The average plant population at harvest was about $78.5 \%$, ranging from 50 (Mafutha) to $93 \%$ (local check and Simama) (Table 4).

Significant differences $(\mathrm{P}<0.05)$ were detected between varieties in root yield and yield components. NC1560 produced higher number of large and total roots per plant than other varieties. The lowest number of roots was produced by Japon tresimesino. NC 1560 also gave the highest yield of large and total fresh storage roots (10.46 and 11.80 tha $^{-1}$, respectively). Tainung No 64 was

TABLE 3. Fresh storage root yield and other attributes of the sweetpotato varieties evaluated on-farm at lkonda, Shinyanga district and five villages in Magu districts in 2001

\begin{tabular}{|c|c|c|c|c|c|c|c|c|}
\hline \multirow[t]{2}{*}{ Variety } & \multicolumn{2}{|c|}{$\begin{array}{l}\text { Large root yield } \\
\qquad\left(t h a^{-1}\right)\end{array}$} & \multicolumn{2}{|c|}{$\begin{array}{l}\text { Total root yieid } \\
\qquad(\mathrm{t} \mathrm{ha-1})\end{array}$} & \multicolumn{2}{|c|}{$\begin{array}{l}\text { Foliage yireld } \\
\qquad\left(\mathrm{tha}^{-1}\right)\end{array}$} & \multicolumn{2}{|c|}{ Harvest index } \\
\hline & Ikonda & Magu & Ikonda & Nagu & Ikonda & Magu & Ikonda & Magu \\
\hline Cemsa74-228 & 9.03 & 6.98 & 9.62 & 7.46 & 2.33 & 4.74 & 0.80 & 0.71 \\
\hline Japon tresimesino & 2.68 & 2.67 & 4.11 & 3.52 & 2.98 & 5.59 & 0.57 & 0.40 \\
\hline Jitihada & 8.64 & 5.59 & 9.19 & 6.08 & 5.11 & 5.78 & 0.63 & 0.51 \\
\hline Sinia & 4.17 & 4.37 & 5.26 & 5.03 & 6.89 & 7.70 & 0.44 & 0.42 \\
\hline Zapallo & 10.27 & 7.44 & 10.92 & 8.02 & 3.31 & 3.59 & 0.77 & 0.69 \\
\hline Tainung No.64 & 7.82 & - & 9.44 & - & 1.61 & - & 0.86 & - \\
\hline NC 1560 & & 6.01 & - & 7.23 & - & 2.59 & - & 0.74 \\
\hline Local check & 5.77 & 4.69 & 6.95 & 5.97 & 2.99 & 7.69 & 0.72 & 0.43 \\
\hline Mean & 6.94 & 5.39 & 7.98 & 6.19 & 3.60 & 5.09 & 0.68 & 0.56 \\
\hline $\mathrm{CV} \%$ & 35.5 & 39.5 & 30.4 & 35.0 & 31.0 & 42.9 & 8.4 & 11.5 \\
\hline $\operatorname{LSD}(0.05)$ & $2.91^{* *}$ & $2.02^{* *}$ & $2.86^{* *}$ & $2.05^{* *}$ & $1.32^{\star \star}$ & $2.07^{\star *}$ & $0.07^{* *}$ & $0.06^{\star *}$ \\
\hline
\end{tabular}

TA.BLE 4. Root yield and other attributes of sweetpotato varieties evaluated on-farm at Kishili in Kwimba district in 2002 season

\begin{tabular}{|c|c|c|c|c|c|c|c|}
\hline \multirow[t]{2}{*}{$\overline{\text { Variety }}$} & \multirow{2}{*}{$\begin{array}{c}\text { Plant } \\
\text { population } \\
\text { at harvest } \\
\%\end{array}$} & \multirow{2}{*}{$\begin{array}{l}\text { Number of } \\
\text { large roots } \\
\text { per plant a }\end{array}$} & \multirow{2}{*}{$\begin{array}{l}\text { Total number } \\
\text { of roots per } \\
\text { per plant }\end{array}$} & \multirow{2}{*}{$\begin{array}{l}\text { Large root } \\
\text { yield ( } \mathrm{ha}^{-1} \text { ) }\end{array}$} & \multirow{2}{*}{$\begin{array}{l}\text { Total root } \\
\text { yield }\left(\mathrm{t} \mathrm{ha}^{-1}\right)\end{array}$} & \multicolumn{2}{|c|}{ Weevil damageb } \\
\hline & & & & & & Cylas & Crown \\
\hline NC 1560 & 86.00 & 4.17 & 6.54 & 10.46 & 11.86 & 1.25 & 2.50 \\
\hline Zapallo & 68.50 & 1.76 & 2.39 & 5.58 & 6.04 & 2.25 & 3.75 \\
\hline Mafutha & 50.25 & 2.25 & 3.07 & 2.99 & 3.42 & 1.25 & 3.00 \\
\hline Tainung No.64 & 71.00 & 2.30 & 3.36 & 6.84 & 7.68 & 2.00 & 3.25 \\
\hline Japon tresimesino & 88.00 & 1.68 & 2.89 & 3.78 & 4.60 & 1.00 & 2.25 \\
\hline Simama & 93.00 & 2.07 & 2.82 & 7.59 & 8.33 & 2.00 & 3.50 \\
\hline Loca checkl) & 93.00 & 2.39 & 2.91 & 10.22 & 10.72 & 1.00 & 2.75 \\
\hline Mean & 78.54 & 2.38 & 3.43 & 6.78 & 7.52 & 1.54 & 3.00 \\
\hline CV\% & 16.53 & 36.17 & 25.84 & 49.79 & 45.81 & 37.14 & 19.47 \\
\hline LSDO.05 & $16.95^{* *}$ & $1.12^{\star \star}$ & $1.16^{* * *}$ & $4.41^{* *}$ & $4.49^{\star \star}$ & $0.85^{*}$ & $0.87^{*}$ \\
\hline
\end{tabular}

$a_{L}$ arge roots have diameter $>=2.5 \mathrm{~cm}$, small roots have diameter $<2.5 \mathrm{~cm}$

beevii damage scores: $1=$ no root damage $5=$ severe infestation of the root, $76 \%<$ of the root damaged by weevils 
the second highest yielder in terms of total root yield $\left(7.68 \mathrm{tha} \mathrm{h}^{-1}\right)$. Mafutha produced the lowest total root yield $\left(3.42 \mathrm{tha}^{-1}\right)$. These results show that some of the introduced varieties have good adaptation to the local conditions, performing better than adapted local cultivars, whose onfarm mean yield are normally below $6 \mathrm{t} \mathrm{ha}^{-1}$ (Lake zone Data Base, 1997)

Farmer assessment of the varieties. At Magu and Kishili all the varieties were highly preferred for root flesh colour except the local checks, which received low scores for flesh root colour. This high-ranking scores of the varieties could have been due to their orange flesh colour.

Farmers' excitement of the importance of orange-fleshed varieties as important source of pro-vitamin A could have influenced their judgement. Farmers rated highly Jitihada, Zapallo, Cemsa 74-228, and NC 1560 for drought tolerance, early maturity and root characteristics. However, Japon tresimesino scored poorly across all the traits except for root skin and flesh colour (orange). This variety had low ratings for most of the traits because root yield was very low. Sinia, on the other hand, got high ratings for most traits but because of its relatively long maturity period, it received low ratings for early maturity and number of roots per plant. The local check, scored consistently higher for all the traits. This was not surprising since farmers only adopt cultivars that meet their preferences as well as adaptability to local environments. The overall acceptability for field performance was rated good to very good for all the varieties, except Japon tresimesino whose root yield was the lowest (Table 5). NC1560 again got the highest overall individual farmers' rating, with Cemsa 74-228 coming second followed by Zapallo, local check (Mwanamulwa) and lastly, Jitihada.

At Kishili, NC 1560 scored highly for all attributes and was ranked first for overall acceptability (Table 6). This is in line with its high fresh root yield at this site. Zapallo, on the other hand, was rated fair to good for most traits, except ground cover and pest resistance. Since this clone has erect type of growth habit, it does not cover the ground properly compared to other clones. This, in part, explains why it received low scores for ground cover. This clone was also susceptible to weevils, particularly when left in the field for a long time. It is an early maturing clone (about three months). This is why it scored highly (4.3) for early maturity (Table 6). Except Japon tresimesino, which is late maturing, all other clones were rated fair to very good ( 3 to 4.8 ) for early maturity. Japon tresimesino matures much later as compared to other varieties and by the time of harvesting and assessment, it was still bulking and thus, exhibited high number of fibrous roots. This was the reason for its lowest score for early maturity, number of roots per plant and root size. The fresh root yield obtained from this clone was also relatively low. The low ratings for this clone with respect to these attributes, made its overall acceptability to rank the lowest.

Assessment of cooked roots. The cooking quality of sweetpotato roots is very important for accepting sweetpotato varieties. Results on root cooking quality assessment across the locations the data are presented inTable 7. All orange varieties,

TABLE 5. Farmer field assessment ${ }^{a}$ of the sweet potato varieties evaluated in Magu district in 2001 season

\begin{tabular}{|c|c|c|c|c|c|c|c|c|c|}
\hline Varieties & $\begin{array}{c}\text { Aesistance } \\
\text { to pest } \\
n=11\end{array}$ & $\begin{array}{c}\text { Tolerance } \\
\text { to drought } \\
n=11\end{array}$ & $\begin{array}{c}\text { Early } \\
\text { maturity } \\
n=11\end{array}$ & $\begin{array}{c}\text { Root per } \\
\text { plant } \\
n=11\end{array}$ & $\begin{array}{c}\text { Root shape } \\
n=11\end{array}$ & $\begin{array}{l}\text { Root skin } \\
\text { colour } \\
n=11\end{array}$ & $\begin{array}{c}\text { Root size } \\
n=11\end{array}$ & $\begin{array}{c}\text { Root flesh } \\
\text { oolour } \\
n=11\end{array}$ & $\begin{array}{c}\text { Overal } \\
\text { acceptability }\end{array}$ \\
\hline Sinia & 4.11 & 3.49 & $2.89^{\circ}$ & 2.78 & 3.78 & 4.22 & 3.78 & 4.33 & 4.0 \\
\hline NC 1560 & 4.22 & 3.89 & 3.89 & 3.78 & 4.33 & 4.22 & 3.67 & 4.56 & 4.78 \\
\hline Cemsa $74-228$ & 4.22 & 4.0 & 4.22 & 3.44 & 3.89 & 3.78 & 4.33 & 4.0 & 4.67 \\
\hline Zapallo & 3.22 & 3.11 & 3.67 & 3.22 & 3.44 & 3.44 & 3.56 & 4.22 & 4.0 \\
\hline Japon tresimesino & 2.67 & 2.56 & 1.44 & 1.78 & 2.44 & 3.33 & 1.78 & 4.0 & 3.11 \\
\hline Jitihada & 3.89 & 3.67 & 4.0 & 4.11 & 4.0 & 3.89 & 4.22 & 4.22 & 4.33 \\
\hline Mwanamulwa & 4.33 & 4.71 & 4.33 & 4.67 & 4.33 & 4.33 & 4.56 & 3.89 & 4.56 \\
\hline Mean & 3.81 & 3.54 & 3.49 & 3.39 & 3.75 & 3.89 & 3.69 & 4.18 & 4.21 \\
\hline $\mathrm{CV}(\%)$ & 20.31 & 19.99 & 18.79 & 22.36 & 21.14 & 21.04 & 17.0 & 19.38 & 17.99 \\
\hline $\operatorname{LSD}(P=0.05)$ & $0.73^{* * *}$ & $0.67^{* k *}$ & $0.62^{\star * *}$ & $0.72^{* *}$ & $0.75^{*}$ & $0.78 \mathrm{NS}$ & $0.60^{* *}$ & NS & $0.72^{\star *}$ \\
\hline
\end{tabular}

a Subjecting rating scores: $1=$ Very bad, $2=$ bad, $3=$ moderate, $4=$ good $5=$ very good 
except Mafutha, were rated very good for appearance, taste, and low for fibrousness but poor for dry texture (low dry matter content). Dry texture, an indication of dry matter content is important when considering the eating habits of people in the lake zone. They tend to select sweetpotato varietics with dry texture (Wolfe, 1992).

The low scores for texture (dry matter content) are not surprising because the orange-fleshed varieties assessed in the present study have low dry matter content (Low et al., 1996).

With respect to root taste, farmers appreciated the good taste of orange-fleshed sweetpotato varieties. All the clones were given high seores for root taste and overall acceptability, except
Mafutha (Table 7). These high ratings signify the high acceptability potential for orange-fleshed sweetpotato varicties. These varieties will adequately fit in the local sweetpotato consumption patterns because of their good taste. This, in turn, will be useful in alleviating problems associated with vitamin A deficiency.

Pair wise rankings of the varieties by farmers are presented in Table 8 . Farmers ranked Tainung No. 64 and Mafutha as first choice, while Japon tresimesino ranked number two. Zapallo and NC 1560 , which were rated bighly for field performance, were ranked in the third position. It is interesting to note that Japon tresimesino, which had the lowest scores for field performance emerged the second for palatability and other

TABLE 6. Farmer assessment of the field performance of sweet potato varieties evaluated at Kishili in Kwimba district in 2002 season

\begin{tabular}{|c|c|c|c|c|c|c|c|c|c|c|}
\hline Varieties & $\begin{array}{l}\text { Ground } \\
\text { cover } \\
n=11\end{array}$ & $\begin{array}{c}\text { Pest } \\
\text { resistance } \\
n=11\end{array}$ & $\begin{array}{c}\text { Drought } \\
\text { tolerance } \\
n=11\end{array}$ & $\begin{array}{c}\text { Early } \\
\text { maturity } \\
n=11\end{array}$ & $\begin{array}{c}\text { Fioots } \\
\text { per } \\
\text { plant }\end{array}$ & $\begin{array}{c}\text { Root } \\
\text { shape } \\
n=11\end{array}$ & $\begin{array}{l}\text { Root } \\
\text { size } \\
n=11\end{array}$ & $\begin{array}{c}\text { Root skin } \\
\text { colour } \\
n=11\end{array}$ & $\begin{array}{l}\text { Root flesh } \\
\text { colour } \\
n=11\end{array}$ & $\begin{array}{c}\text { Overall } \\
\text { acceptability }\end{array}$ \\
\hline NC 1560 & 4.00 & 4.00 & 4.50 & 4.80 & 4.60 & 4.30 & 3.80 & 3.90 & 4.10 & 4.90 \\
\hline Zapallo & 2.80 & 2.70 & 3.00 & 4.30 & 3.30 & 3.70 & 3.80 & 3.90 & 3.90 & 3.40 \\
\hline Mafutha & 2.80 & 3.00 & 3.00 & 3.00 & 3.20 & 3.10 & 3.00 & 3.50 & 3.50 & 3.30 \\
\hline Tainung No.64 & 2.50 & 2.80 & 2.90 & 3.50 & 3.60 & 4.20 & 3.80 & 4.10 & 4.10 & 3.80 \\
\hline Japon tresimento & 2.20 & 3.40 & 3.60 & 1.80 & 1.70 & 2.80 & 2.10 & 3.50 & 3.50 & 2.90 \\
\hline Simama & 3.70 & 3.90 & 4.50 & 4.20 & 4.00 & 3.60 & 4.30 & 4.20 & 3.70 & 4.30 \\
\hline Loca checkl) & 4.30 & 4.20 & 4.20 & 4.20 & 3.60 & 3.40 & 3.90 & 3.60 & 2.90 & 3.70 \\
\hline Mean & 3.19 & 3.43 & 3.67 & 3.69 & 3.43 & 3.59 & 3.53 & 3.81 & 3.67 & 3.76 \\
\hline CV\% & 30.90 & 224.01 & 23.82 & 19.61 & 24.14 & 24.38 & 21.26 & 19.99 & 25.86 & 20.52 \\
\hline LSDO.05 & $0.88^{\star \star \star}$ & $0.74^{* *}$ & $0.78^{\star \star}$ & $0.64^{* * *}$ & $0.74^{* *}$ & $0.78^{\star}$ & $0.67^{*}$ & NS & NS & $0.69^{\star \star \star *}$ \\
\hline
\end{tabular}

1 Farmers assessment scores: $1=$ very poor $2=$ poor $3=$ fair $4=$ good $5=$ =very good

TABLE 7. Farmer assessment ${ }^{a}$ of cooked roots of the sweet potato varieties evaluated at Kishili village in Kwimba district in 2002

\begin{tabular}{|c|c|c|c|c|c|}
\hline Variety & $\begin{array}{c}\text { Root } \\
\text { appearance } \\
N=10\end{array}$ & $\begin{array}{l}\text { Root taste } \\
\qquad N=10\end{array}$ & $\begin{array}{l}\text { Texture } \\
\text { (dry matter } \\
\text { content) }\end{array}$ & $\begin{array}{l}\text { Fibroussness }^{b} \\
\qquad N=10\end{array}$ & $\begin{array}{l}\text { Acceptability } \\
N=10\end{array}$ \\
\hline NC 1560 & 3.30 & 4.40 & 2.50 & 3.30 & 4.00 \\
\hline Zapallo & 3.40 & 3.70 & 3.40 & 3.20 & 4.20 \\
\hline Mafutha & 2.20 & 2.00 & 3.80 & 3.50 & 2.40 \\
\hline Tainung No.64 & 3.70 & 3.80 & 1.60 & 2.50 & 3.60 \\
\hline Japon tresimento & 3.60 & 3.00 & 1.90 & 3.10 & 4.10 \\
\hline Simama & 3.90 & 3.80 & 4.00 & 3.40 & 4.10 \\
\hline Loca chckl) & 4.40 & 3.90 & 2,00 & 3.40 & 4.10 \\
\hline Mean & 3.50 & 3.51 & 2.74 & 3.20 & 3.64 \\
\hline $\mathrm{CV} \%$ & 32.56 & 35.36 & 37.74 & 25.33 & 32.17 \\
\hline LSD0.05 & $1.022^{\star \star}$ & $1.11^{\star \star}$ & $0.93^{* \star}$ & NS & $1.05^{* *}$ \\
\hline
\end{tabular}

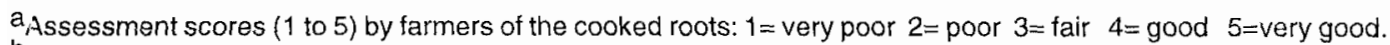

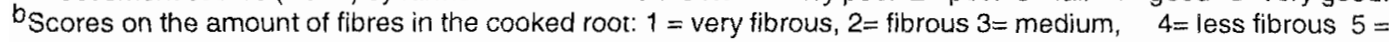
not tibrous 
cooking qualities. This trend was also the same for Mafutha and Tainung No. 64, which were ranked poorly for field performance, but rated higher for cooking qualities. These differences in the performance and perception of the varieties by the farmers indicate that varieties can be adopted for different uses. Varieties that performed better in the field did not necessary appeal to the farmers after cooking. Considering the importance of the orange-fleshed sweetpotato as source of vitamin A, farmers were suggesting that varieties that did not taste to their expectations could be processed into dry chips called michembe or matoborwa. Farmers also attached high preferences to orange varieties because they are swecter than whitefleshed varieties. Other reasons given by the farmers for the preferences and acceptability of the new orange varieties included early maturity, good root yield, numerous large roots, soft roots when cooked (suitable for children), sweet taste, good root flesh colour and appearance. This high acceptability of the clones for cooking qualitics and other traits will greatly increase their adoption rates.

Children were also involved in the taste tests of orange varieties because they are vulnerable to vitamin A deficiency. It is known (Kapinga etal., 1995) that daily intake of orange-fleshed sweetpotato varicties will meet daily dictary requirements of vitamin A. Only little amount of fresh swectpotato roots is requircd to supply the daily requirement of pro-vitamin A (Low et al, 1996; Carey et al., 1999; Low et al., 2000). For example, children of four to six years of age will require only $43 \mathrm{~g}$ of orange varieties to meet their vitamin A daily requirements of $500 \mathrm{mcg}$ retinoequivalent. To mect the same daily requirement, they will need $4.5 \mathrm{~kg}$ ( $4545 \mathrm{~g}$ ) of white-fleshed sweetpotato roots (Carey et al., 1999), which is beyond the amount any one can consume in a day. This means that for poor households, the production and consumption of orange-fleshed sweetpotatoes can be the most effective and sustainable control strategy for vitamin A deficiency in children.

Results obtained from the taste tests of cooked roots by school children at Kishili village in Kwimba district show ratings largely as fair (Table 9). This was also true with respect to overall acceptability of the varieties. To most children, it was the first time to come across orange-fleshed swcetpotato roots. Children were strongly attracted, fascinated and appealed by the orange flesh colour. This was reflected in their higher ratings for the varieties for root flesh colour. The importance attached to the orange colour by the children could have attracted them to consume more orange-fleshed sweetpotato varieties regularly. This will permit them to meeting their daily requirement of vitamin $A$.

Results of the taste tests of the products at Nyanguge are presented in Table 10. It was interesting to note that all the products made from orange-fleshed roots scored higher than those made from white-fleshed roots with respect to taste, internal colour, and external colour. This indicated a higher preference for products from orange-fleshed roots than from white-fleshed

TABLE 8. Pair wise comparisons in ranking the cooking quality of sweet potato varieties evaluated at Kishili in K wimba district in 2002

\begin{tabular}{|c|c|c|c|c|c|c|c|}
\hline Variety & $\begin{array}{c}\text { Japon } \\
\text { tresimesino }\end{array}$ & Zapallo & afutha & Tainung NO64 & NC 1560 & Simama & $\begin{array}{l}\text { Mwana- } \\
\text { mulwa }\end{array}$ \\
\hline Japon tresimesino & * & & & & & & \\
\hline Zapallo & Japon & * & & & & & \\
\hline Mafutha & Mafutha & Mafutha & $*$ & & & & \\
\hline \multicolumn{8}{|l|}{ Tainung } \\
\hline NO. 64 & Tainung No.64 & Tainung NO 64 & Tainung NO 64 & * & & & \\
\hline NC 1560 & Japon & Zapallo & Mafutha & Tainung NO 64 & & & \\
\hline Simama & Japon & simama & Mafutha & Tainung NO 64 & NC 1560 & * & \\
\hline Mwanamulwa & Japon & Zapallo & Mafutha & Tainung NO 64 & NC 1560 & Simarna & \\
\hline Total frequency scores & 4 & 2 & 5 & 6 & 2 & 2 & 0 \\
\hline Ranking & 2 & 3 & 1 & 1 & 3 & 3 & 4 \\
\hline
\end{tabular}


roots. Farmers in this area, for example, did not prefer doughnuts made from white-fleshed roots, so they were rated bad for taste, internal colour, and overall acceptability (Table 10).

At Kishili, almost similar results were obtained (Table 11). Although farmers rated products from orange-fleshed roots higher than from whitefleshed, the magnitude of the scores implied that products from white-fleshed roots (except for doughnuts) were fairly acceptable.

Since all the sexes were involved in assessing the products, analysis was done to evaluate the effect of gender on taste and other attributes of the prepared products. Significant $(\mathrm{P}<0.05)$ differences existed between female and male tasters for taste only. The scores for taste of different products were significantly $(\mathrm{P}<0.05)$ higher for women than men, except for the taste of kaimat prepared from white-fleshed roots. These preliminary results show that the different sexes may prefer different products.

In general, farmers preferred the products made from orange sweetpotatoes. Their major reasons for preference were that the products' sweetness,

TABLE 9. Assessment ${ }^{\mathrm{a}}$ by children of the cooked roots of the sweet potato varieties evaluated at Kishili village in Kwimba district in 2002 .

\begin{tabular}{lccc}
\hline Variety & $\begin{array}{c}\text { Root taste } \\
n=21\end{array}$ & $\begin{array}{c}\text { Root colour } \\
n=21\end{array}$ & $\begin{array}{c}\text { Acceptability } \\
n=21\end{array}$ \\
\hline NC 1560 & 3.38 & 3.95 & 3.43 \\
Zapallo & 3.38 & 3.66 & 3.33 \\
Mafutha & 3.29 & 3.81 & 3.33 \\
Tainung No.64 & 3.19 & 3.91 & 3.09 \\
Japon tresimento & 3.33 & 3.62 & 3.14 \\
Simama & 3.24 & 3.76 & 3.14 \\
Loca check) & 3.19 & 3.52 & 3.19 \\
& & & 3.24 \\
Mean & 3.29 & 3.75 & 21.52 \\
CV\% & 18.07 & 10.29 & $\mathrm{NS}$ \\
LSD 0.05 & $\mathrm{NS}$ & $0.24^{* *}$ & \\
\hline
\end{tabular}

assessment scores ( 1 to 5 ) by children of the cooked roots: $1=$ very poor $2=$ poor $3=$ fair $4=$ good $5=$ very good

TABLE 10. Farmers' assessment and overall acceptability of sweet potato secondary products from sweet potato varieties evaluated at Nyanguge in Magu District, 2000/2001

\begin{tabular}{|c|c|c|c|c|c|}
\hline Product & $\begin{array}{l}\text { Taste } \\
N=11\end{array}$ & $\begin{array}{l}\text { Shape } \\
N=11\end{array}$ & $\begin{array}{l}\text { Internal colour } \\
\qquad N=11\end{array}$ & $\begin{array}{l}\text { External colour } \\
\qquad N=11\end{array}$ & $\begin{array}{c}\text { Overall acceptability } \\
\qquad N=11\end{array}$ \\
\hline Cake orange ${ }^{a}$ & 4.40 & 4.10 & 4.70 & 4.30 & 4.50 \\
\hline Cake white $b$ & 3.30 & 3.10 & 2.60 & 3.40 & 3.00 \\
\hline Doughnut orange & 4.40 & 4.10 & 4.40 & 4.10 & 4.00 \\
\hline Doughnut White & 2.90 & 3.30 & 2.80 & 3.70 & 2.50 \\
\hline Buns orange & 4.20 & 4,30 & 4.70 & 4.30 & 4.10 \\
\hline Buns White & 3.80 & 3.60 & 3.20 & 3.90 & 3.20 \\
\hline Pancake orange & 5.00 & 4.70 & 4.60 & 4.70 & 4.30 \\
\hline Pancake White & 4.30 & 4.80 & 3.96 & 4.50 & 3.60 \\
\hline Kaimat orange & 4.80 & 4.70 & 4.40 & 4.60 & 4.90 \\
\hline Kaimat White & 4.40 & 4.00 & 3.90 & 3.90 & 3.90 \\
\hline Mean & 4.15 & 4.07 & 3.97 & 4.14 & 3.80 \\
\hline CV \% & 14.87 & 5.51 & 17.81 & 15.31 & 23.79 \\
\hline $\operatorname{LSD}(0.05)$ & $0.55^{* *}$ & $0.56^{\star \star}$ & $0.63^{\star *}$ & $0.56^{* *}$ & $0.80^{\star *}$ \\
\hline
\end{tabular}

Subjective rating scores; $1=$ very bad, $2=$ bad, $3=$ moderate, $4=$ good $5=$ very good

a orange $=$ products prepared from orange -fleshed varieties,

$b_{\text {white }}=$ products prepared from white-fleshed varieties 


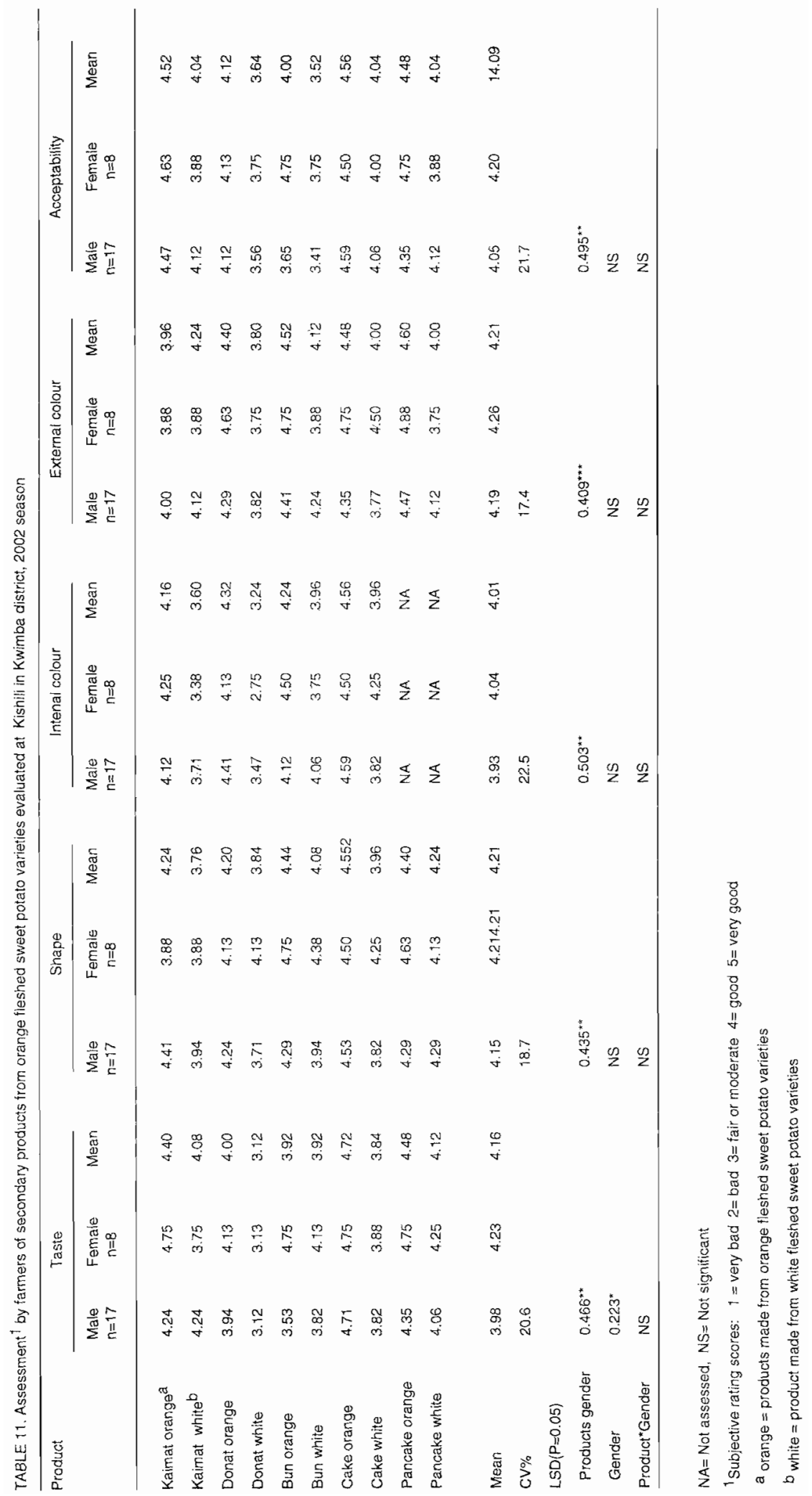


TABLE12. Assessment of secondary products from orange fleshed sweet potato varieties by school children at Kishili in Kwimba district in 2002

\begin{tabular}{lccc}
\hline Product & & Attributes & \\
\cline { 2 - 3 } & Taste & Internal colour & Acceptability \\
\hline Kaimati crange & 3.65 & 3.65 & 3.85 \\
Kaimati White & 3.35 & 3.60 & 3.60 \\
Donati Orange & 3.50 & 3.75 & 3.40 \\
Donati White & 3.10 & 3.30 & 3.25 \\
Bun Orange & 3.30 & 3.85 & 3.55 \\
Bun White & 3.40 & 3.65 & 3.40 \\
Cake Orange & 3.85 & 3.60 & 3.80 \\
Cake White & 3.50 & 3.30 & 3.60 \\
Pancake Orange & 3.60 & 3.70 & 3.85 \\
Pancake White & 3.35 & 3.60 & 3.50 \\
& & & 3.58 \\
Mean & 3.46 & 3.60 & 16.45 \\
CV\% & 14.68 & 13.77 & $0.36^{* *}$ \\
LSD (0.05) & $0.31^{* *}$ & $0.30^{\star *}$ & \\
\hline
\end{tabular}

Assessment scores ( 1 to 5 ) by children of sweet potato products: $1=$ very poor $2=$ poor $3=$ fair $4=$ good $5=$ very good

good appearance and attractive internal colour. Also, the flour made from orange-fleshed roots was fine and could easily be mixed with other ingredients than one from white-fleshed roots. The high preference for these products implies that they are highly acceptable. If adopted, this product diversification will in the long run lead to increased consumption of orange-fleshed sweetpotatoes. The production of these varieties will, therefore, be increased.

As for cooking qualities of the roots, children were involved in the assessment of the different products made from sweetpotato roots. For simplicity only taste, internal colour and acceptability were considered. At all the sites children rated higher the products from orangefleshed roots than from white-fleshed roots for all the attributes except for taste of buns (Table 12). As for cooked roots, children were more attracted by orange colour than white. This attraction may support regular consumption of products from the orange-fleshed roots, thus, reducing vitamin A deficiencies.

\section{ACKNOWLEDGEMENTS}

We are grateful to CIP/ SARRNET for funding this project. The farmers and NGOs evaluated the varieties and the Zonal Director of Research and
Development in the Lake Zone provided administrative support.

\section{REFERENCES}

Carey, E.E., Hagenimana, V., K'osambo, L., Oyunga, M.A., Benesi, I., Smit, N., Ocitti p'Obwoya, C., Turyamureeba, G., Ndolo, P.J., and Low, J. 1999. Using orange-fleshed sweetpotato varieties to combat vitamin $\mathrm{A}$ deficiency and enhance market opportunities for smallholder farmers in sub-Saharan Africa. In: Food Security and Crop Diversification in SADC Countries: The Role of Cassava and Sweetpotato, M.O. Akoroda and J.M. Teri (Eds.), pp. 157-168. Proceedings of the scientific workshop of the Southern African Root Crops Research Network (SARRNET) held at Pamodzi Hotel, 17-19 August, 1998, Lusaka, Zambia. 476p.

Kapinga, R.E, Ewell, P.T., Jeremiah, S.C. and Kileo, R. 1995. Sweetpotato in Tanzania farming and Food Systems: Implications for Research. Internationl Potato Center and Ministry of Agriculture Tanzania.

Lake Zone Data Base. 1997. Main sweetpotato production statistics 1993/94. Lake Zone Agricultural Research Institute, Tanzania. 
Low, J., Uaiene, R., Andrade, M.I. and Howard, J. 2000. Orange fleshed sweetpotato: Promising partnerships for assuring the integration of nutritional concerns into Agricultural Research and Extension in Mozambique. FlashNo.20E. Research Results from the Department of Policy Analysis, MARD- Directorate of Economics.

Low, J., Kinyae, p., Gichuki, S., Onyango, M.A., Hagenimana, V. and Kabira, J. 1996. Combating Vitamin A deficiency through the use of sweetpotato. International Potato Center and Kenya Agricultural Research Institute.

VITAA 2000. Eradicating childhood blindness in Africa: The promise of orange-flesh sweetpotato. The International Potato Center Newsletter.
Wamara, F.H.A. 1997. Baseline survey report in Magu district. CARE-International, Tanzania. Walker, T., Low, J. and Hijmans, R. 2001. The potential impact of orange-fleshed sweetpotato on Vitamin-A intake in sub-Saharan Africa. Paper presented at a Regional Workshop on Food Based Approaches to Human Nutritional Deficiencies: The VITAA Project, Vitamin A and Orange-fleshed sweetpotato in subSaharan Africa. May 9-11, 2001. Nairobi, Kenya

Wolfe, J.A. 1992. Sweetpotato: an Untapped Food Resource. Cambridge. Cambridge University Press.U.K. 